\title{
Do IFRS Promote Transparency? Evidence from the Bankruptcy Prediction of Privately Held Swedish and Norwegian Companies
}

\author{
Akarsh Kainth ${ }^{1, *(\mathbb{D})}$ and Ranik Raaen Wahlstrøm ${ }^{2}$ (D) \\ 1 Department of International Business, Norwegian University of Science and Technology, \\ 6009 Ålesund, Norway \\ 2 NTNU Business School, Norwegian University of Science and Technology, 7491 Trondheim, Norway; \\ ranik.raaen.wahlstrom@ntnu.no \\ * Correspondence: akarsh.kainth@ntnu.no; Tel.: +47-70161407
}

Citation: Kainth, Akarsh, and Ranik Raaen Wahlstrøm. 2021. Do IFRS Promote Transparency? Evidence from the Bankruptcy Prediction of Privately Held Swedish and Norwegian Companies. Journal of Risk and Financial Management 14: 123 https://doi.org/10.3390/jrfm14030123

Academic Editor: S. Abraham Ravid

Received: 16 February 2021

Accepted: 11 March 2021

Published: 15 March 2021

Publisher's Note: MDPI stays neutral with regard to jurisdictional claims in published maps and institutional affiliations.

Copyright: (c) 2021 by the authors. Licensee MDPI, Basel, Switzerland This article is an open access article distributed under the terms and conditions of the Creative Commons Attribution (CC BY) license (https:// creativecommons.org/licenses/by/ $4.0 /)$

\begin{abstract}
The purpose of our paper is to investigate whether any differences between International Financial Reporting Standards (IFRS) and local Generally Accepted Accounting Principles (GAAP) impact the transparency of financial reporting of non-listed companies through bankruptcy prediction. This contributes to extant research that has focused on the effects of IFRS adoption in the context of listed companies. For our investigation, we used logistic regression, well-established accountingbased predictors, and a sample of financial statements from privately held Swedish companies using IFRS, and Norwegian companies using Norwegian GAAP. The results indicate that financial statements made under IFRS may be better suited for bankruptcy prediction than those made under Norwegian GAAP. Our findings suggest that the use of IFRS could aid in increasing the informativeness of financial reports by promoting transparency and prevent managers of firms facing insolvency from engaging in creative accounting practices. Our results should, however, be applied with caution, as they may be due to the differences in characteristics across firms that are not captured by our research design. We leave this issue open to future research.
\end{abstract}

Keywords: IFRS; accounting standards and principles; bankruptcy prediction; transparency; privately held companies; Norwegian GAAP; logistic regression; accounting-based predictors

\section{Introduction}

Predicting company bankruptcy is at the core of credit risk management and thus important for academics, regulators and practitioners (Bărbută-Misu and Madaleno 2020). Since the input variables of models used for bankruptcy predicting often are derived from financial statements, it is important that these are transparent. International Financial Reporting Standards (IFRS) are widely used for financial reporting and promote cross-country comparability and more transparency than local Generally Accepted Accounting Principles (GAAP) through the use of fair values and more disclosure requirements (Diamond and Verrecchia 1991; Levitt 1998; Botosan and Plumlee 2002; International Standards Accounting Board 2002; Lambert et al. 2007; George et al. 2016; Fossung et al. 2020). Thus, the use of IFRS can prevent managers from engaging in creative accounting practices in order to mask the credit risk of their companies (Bhat et al. 2014; Bodle et al. 2016). All of this should make financial statements based on IFRS more relevant to stakeholders than those based on local GAAP. In this paper, we evaluate this by investigating whether the use of IFRS relative to local GAAP improves the transparency of financial reporting through bankruptcy prediction.

A financial report presents the financial position and performance of a company. When preparing a financial report, the choice of accounting regulations is of great importance, since different regulations yield different accounting figures, resulting in varied perceptions of a company. For example, the 110 companies listed on the Oslo Stock Exchange in 2005 experienced a $17 \%$ increase in net income on average, after restating their 2004 financial 
statements from the Norwegian GAAP (NGAAP) to IFRS, which Gjerde et al. (2008) argue is mainly due to differences in accounting for goodwill and intangible assets under the two sets of regulations. First, development expenditures are recognized as intangible assets under IFRS, while NGAAP provide a widely used option to expense them immediately. Second, goodwill is subject to amortization under NGAAP, while IFRS require that it be tested annually for impairment. Third, expenditure on brands is recognized as an intangible asset under NGAAP but not under IFRS (Norwegian Accounting Standards Board 2012; Picker et al. 2016; Bodle et al. 2016; IFRS Foundation 2021). Given these differences, we expect that the use of IFRS will lead to a change in transparency and thus the assessment of bankruptcy prediction, especially when using accounting-based variables.

We used a comprehensive sample of 2,290,551 annual financial statements from privately held Swedish and Norwegian companies based on IFRS and NGAAP, respectively, spanning the time period of 2006-2018. Furthermore, we predicted company bankruptcy using logistic regression (LR) and the input variables from Altman (1968) and the SEBRA model developed by the central bank of Norway. Our findings suggest that financial statements based on IFRS yield better bankruptcy prediction models, compared to those based on NGAAP, both in terms of in-sample fit and out-of-sample performance.

We contribute to the literature in the following ways. First, our study focuses on the role of accounting standards in bankruptcy prediction-an area which to the best of our knowledge has not been researched extensively. Second, our study is among the few that focus on the benefits of IFRS for creditors while the majority of the existing literature has investigated the effects of IFRS adoption on equity markets, cost of capital, cross country comparability and corporate investment efficiency (George et al. 2016). Third, to the best of our knowledge, we are the first to investigate whether the alleged benefits of IFRS also apply to bankruptcy prediction in the Scandinavian market. Our choice of market thus differs from most studies on bankruptcy prediction, which have used data from the United States of America (Appiah et al. 2015; Bodle et al. 2016). A study related to ours is that of Bodle et al. (2016), which found that financial reporting under IFRS yields better capabilities in terms of bankruptcy prediction models, compared to financial reporting under Australian GAAP. However, the authors used only listed companies, which is, indeed, the convention in the bankruptcy prediction literature (Appiah et al. 2015). By contrast, our analysis of medium- and large-sized privately held Swedish companies is particularly relevant, as such companies can choose to prepare their consolidated financial statements under IFRS. Consequently, IFRS have considerable legitimacy in Sweden (IFRS Foundation 2016; Marton 2017).

The rest of this paper is structured as follows. Section 2 reviews the literature on IFRS and their impact on value relevance, forecasting accuracy, credit ratings, and bankruptcy prediction. Section 3 describes the data and sampling choices, and Section 4 describes the research method. The results are presented and discussed in Section 5. Finally, the conclusions are given in Section 6.

\section{Literature Review}

We review the literature on the impact of IFRS on (i) value relevance, (ii) forecasting accuracy, and (iii) credit ratings and bankruptcy prediction. All of these areas can be regarded as providing evidence on the transparency of financial reporting (Singleton-Green 2015).

\subsection{IFRS and Value Relevance}

Financial reports are value relevant if their accounting numbers are correlated with stock market prices. Thus, if the economic reality is reflected in market prices, then value relevant financial reports are transparent, as their accounting numbers will reflect the economic reality. This also results in other benefits, such as an increased comparability of financial reports and improved efficiency of capital markets (George et al. 2016).

Studies have reported that using IFRS rather than local GAAP leads to an increased value relevance of financial reports (Bartov et al. 2005; Singleton-Green 2015). For instance, 
Barth et al. (2008) found that adopting International Accounting Standards (IAS) yields more value relevant financial reports in a sample of 327 adopters and non-adopters across 21 countries in the time period of 1992-2009. ${ }^{1}$ Moreover, Horten and Serafeim (2010) suggested that financial reports under IFRS promote more value relevance through the credible communication of bad news, compared to financial reports under UK GAAP.

On the contrary, several studies found a weak relationship or no relationship between IFRS and value relevance. For instance, Hung and Subramanyam (2007) studied a sample of 80 German companies that adopted IAS during the time period of 1998-2002 and found that accounting standards did not have a major impact on value relevance. They found only weak evidence of a higher timeliness of IAS income, compared to local GAAP income, and that IAS adjustments were value relevant for the book value of equity, but not for net income. Furthermore, Oliveira et al. (2010) studied 32 Portuguese companies over the time period of 1998-2008 and found that using IFRS, instead of local GAAP, yields a lower value relevance of earnings, no change in the value relevance of the book value of equity and intangibles, and a higher value relevance of goodwill. In a similar vein, Christiansen et al. (2015) and Günther et al. (2009) found no change in value relevance when using IFRS, instead of German GAAP. Moreover, Ates (2021) used a sample of listed companies from 11 European Union countries and found that the use of IFRS led to increased value relevance of earnings per share and no significant impact on the value relevance of book value per share.

Some studies have found that the value relevance of intangibles is lower when using IFRS. For instance, a study by Cordazzo and Rossi (2020) based on a sample of nonfinancial listed Italian firms from 2000 to 2015 found that intangibles as a whole were not value relevant under IFRS, except for goodwill and research and development expenditures. However, when they divided the sample into intangible-intensive or non-intangibleintensive firms, the value relevance of research and development expenditures fell after the IFRS adoption. In a similar vein, a study by Paolone et al. (2020) based on a sample of Italian listed firms in the period 2010-2018 found that intangibles such as goodwill and research and development expenditures were positively related to stock prices. By contrast, Güleç (2021) claimed no change in the value relevance of research and development expenditures under IFRS.

In summary, there is a lack of consensus on whether using IFRS, instead of local GAAP, affects the value relevance of financial reports. Moreover, the different findings in the above-mentioned studies reflect the differences in the markets and time periods covered. The differences in findings could also be due to any changes in the accounting standards and principles over time.

\subsection{IFRS and Forecasting Accuracy}

Tan et al. (2011) and Choi et al. (2013) found that financial analysts' earnings forecasts were more accurate when based on financial reports under IFRS, compared to financial reports under UK GAAP for mandatory UK IFRS adopters in the period of 2003-2007. Furthermore, Wang et al. (2008) examined the effects of mandatory IFRS adoption in 2005 for a sample of 1438 firms in 17 European countries during the period of 2005-2006. They found significantly more accurate financial analysts' earnings forecasts for the postIFRS adoption period than for the pre-IFRS adoption period. However, this finding was not so obvious when the authors divided the countries into legal origin groups. In particular, they found more accurate financial analysts' earnings forecasts for the French legal origin group but no significant change in accuracy for the German legal origin group. Byard et al. (2010) found that financial analysts' earnings forecasts were more accurate and less dispersed when using accounting numbers based on IFRS for 1168 mandatory adopters in 20 European countries for the time period of 2005-2006. However, this applied

1 IAS are related to IFRS to a high degree. The IAS were published by the International Accounting Standards Committee (IASC) between 1973 and 2000. In 2000, IASC restructured itself into the International Accounting Standards Board (IASB), adopted all the IAS standards, and named the future standards IFRS (IFRS Foundation 2020). 
only to IFRS adopters domiciled in countries with both strong enforcement regimes and significantly different reporting practices under local GAAP, compared to IFRS. Further, Kwon et al. (2019) found that the use of IFRS led to more accurate earnings forecasts for a sample of firms listed on the Korean Stock Exchange. In a similar vein, Masoud (2017) investigated 66 companies listed on the Amman Stock Exchange and found that earnings forecasts were more accurate under IFRS. Hence, it appears that using IFRS results in better earnings forecast accuracy.

\subsection{IFRS, Credit Ratings, and Bankruptcy Prediction}

Bodle et al. (2016) used a sample of 46 listed Australian companies that went bankrupt in the period of 1991-2004 and found that the accounting numbers based on IFRS predicted bankruptcy better than those based on Australian GAAP due to the increased transparency and conservative accounting rules for intangibles under IFRS. This is consistent with Florou and Kosi (2015), who found lower bond yield spreads for companies using IFRS, and Florou et al. (2017), who found that the accounting numbers of listed companies explained credit ratings better after the introduction of mandatory IFRS reporting in 2005. Furthermore, Charitou et al. (2015) found that IFRS were beneficial to the market, as companies with a higher default risk exhibited deteriorating characteristics after they started using IFRS. In addition, Wu and Zhang (2014) documented a significant increase in the sensitivity of credit ratings with the adoption of IFRS. On the other hand, Kraft and Landsman (2020) found no clear evidence of the credit relevance of accounting numbers after mandatorily switching to IFRS. Similarly, Bhat et al. (2014) found that adopting IFRS yields no change in the ability of earnings, the book value of equity, and the leverage to explain credit risk prices.

\section{Data}

It is difficult to obtain enough financial reports for model estimation and evaluation from the same companies and same accounting years based on IFRS and local GAAP separately as most companies make financial statements for an accounting year under a single set of accounting standards. Consequently, we consider two similar Scandinavian countries by including annual financial statements of (i) Swedish companies made under IFRS, retrieved through the Orbis database, and (ii) Norwegian companies made under NGAAP, provided by the Norwegian governmental agency, Brønnøysund Register Centre. ${ }^{2}$ By using accounting data from the two countries, we obtain enough financial statements to compare the results of using local GAAP and IFRS, within the same accounting years. Thus, we eliminate any time period effects. However, as national cultures can impact accounting measurements and financial reporting practices, our results could potentially be affected by cross-country differences (Kanagaretnam et al. 2014). Guermazi and Halioui (2020) found that individualism and uncertainty avoidance are two important dimensions of national culture that influence behavior in terms of the implementation of accounting standards. Norway scores 69 and 50, whereas Sweden scores 71 and 29 for these dimensions, respectively. The scores for individualism are almost similar, meaning that both nations are characterized by an individualistic culture. The scores differ, however, in terms of uncertainty avoidance. The score of 50 for Norway does not indicate any preference for avoiding uncertainty, while the score of 29 for Sweden indicates a very low preference (Hofstede Insights 2020). Overall, it appears that both countries are similar in terms of cultural dimensions that could impact the accounting practice. Hence, we assume that any effects due to cross-country differences in our data can be deemed negligible. Moreover, the local GAAP of Norway and Sweden are also very similar to each other in practice (Kristoffersen 2020).

We include financial statements of privately held limited liability companies, spanning over the time period of 2006-2018. Furthermore, we include only financial statements of

2 Restrictions apply to the availability of these data. The web pages for the data providers are www.orbis.bvdinfo.com and www.brreg.no, respectively. 
medium- or large-sized companies, which we define in accordance with the Orbis database as those with a turnover above EUR 1 million or total assets above EUR 2 million. ${ }^{3}$ Following the common convention in the literature, we exclude all financial statements operating in the banking, real estate, and public utility sectors (Mansi et al. 2012). Further, we exclude financial statements that have missing values for any of the accounting indicators used for deriving our input variables. ${ }^{4}$ In accordance with the central bank of Norway, we categorize financial statements as bankrupt if they are the last of their company to which they belong, and the company has filed for bankruptcy (Bernhardsen and Larsen 2007). All other financial statements are categorized as non-bankrupt. Our final data sample consists of 1,892,294 financial statements using NGAAP, of which $1.8 \%$ are categorized as bankrupt, and 347,159 financial statements using IFRS, of which 1.5\% are categorized as bankrupt.

In keeping with the recent bankruptcy prediction literature (e.g., Tian et al. 2015), we chose to use the real population of observations and to refrain from performing any matching in order to achieve a balanced dataset with an equal number of bankrupt and non-bankrupt financial statements. This is in line with Zmijewski (1984), who argued that the capability of a bankruptcy prediction model is distorted if it is estimated using a constructed dataset with a ratio of bankrupt to non-bankrupt observations that deviates from the real population.

\section{The Input Variables}

Since we are studying the effects of accounting standards, we use accounting-based input variables. Our initial set of variables is taken from the bankruptcy prediction model of Altman (1968) and the SEBRA model for bankruptcy prediction developed by the central bank of Norway. The former has been proven to perform well across different country settings (Altman et al. 2017) and is widely used by practitioners and academics (Begley et al. 1996; Grice and Ingram 2001; Mansi et al. 2012; Appiah et al. 2015; Tian et al. 2015; Bodle et al. 2016; Tian and Yu 2017). The latter is developed for Norwegian companies and is used by the Financial Supervisory Authority of Norway (Bernhardsen and Larsen 2007). Paraschiv et al. 2021) proved empirically that the variables of the SEBRA model yield good predictions when used with recent financial statements from privately held companies. Our initial set of variables is shown in Table 1 and measures liquidity, profitability, leverage, solvency, and company size. We do not consider the variable measuring activity which is present in the model of Altman (1968) as it has been found to be insignificant and industry sensitive (Altman 1968, 1993). Furthermore, this is also consistent with Vo et al. (2019) and Ntoung et al. (2020) who also predicted bankruptcy with the accounting-based variables of Altman (1968) but without the variable measuring activity.

Altman (1968) used the market value of equity in the numerator of the variable, BVEQ/TL. Instead, we follow the revised model of Altman (1993), using the book value of equity. This is in accordance with the claim that book-debt ratios are better than marketdebt ratios, as debt issued against the latter can distort future investment decisions, which is due to the fact that market values incorporate present values of future growth opportunities (Moyer 1977; Shyam-Sunder and Myers 1999). Further, as the book value of equity is not directly available in the Orbis database, we calculate it by subtracting total liabilities from total assets. Moreover, as retained earnings are not commonly reported by privately held companies in the Orbis database, we use "Other shareholder funds" as a proxy. This item also includes profits for the fiscal year, treasury reserves, voluntary provisions, and other minority interests (Orbis 2007). However, this is deemed acceptable, as all of these items reflect the company's savings (Fan and Kalemli-Ozcan 2015).

\footnotetext{
3 The Orbis database also uses the number of employees for defining size. We, however, do not rely on this, as it is not available for all our data.

4 This constitutes $0.5 \%$ of the financial statements in our remaining data set.
} 
Table 1. The initial set of input variables used in this paper. The first four are taken from Altman (1968) with the book value of equity in the variable BVEQ/TL, as suggested by Altman (1993). The remaining are taken from the SEBRA model developed by the central bank of Norway (Bernhardsen and Larsen 2007).

\begin{tabular}{ccc}
\hline Variable & Category & Description \\
\hline WC/TA & Liquidity & Working capital to total assets \\
\hline RE/TA & Leverage & Retained earnings to total assets \\
\hline EBIT/TA & Profitability & Earnings before interest and taxes to total assets \\
\hline BVEQ/TL & Solvency & Book value of equity to total liabilities \\
\hline BVEQ/TA & Leverage & Book value of equity to total assets \\
\hline dEQ & Solvency & Dummy: one if book value of equity is less than paid in capital \\
\hline LIQ/REV & Liquidity & Cash and cash equivalents less current liabilities to operating revenue \\
\hline logTA & Size & The natural logarithm om total assets in EUR \\
\hline PA/TA & Liquidity & Trade payables to total assets \\
\hline
\end{tabular}

Following the existing literature, ${ }^{5}$ we restrict the values of the non-dummy input variables between the 5th and 95th percentiles across the financial statements based on IFRS and NGAAP, respectively, for each accounting year. If the denominator of a ratio variable is zero and its numerator is positive (negative) then the variable value is set to the maximum (minimum), i.e., the 95th (5th) percentile. If both the numerator and denominator are zero, the variable value is set to zero.

To avoid multicollinearity, we exclude several input variables from our initial set in Table 1. The exclusions are based on the Pearson correlation coefficient between the pairs of input variables and the variance inflation factor for each input variable $i$ calculated as:

$$
V I F_{i}=\frac{1}{1-R_{O L S}^{2}}
$$

where $R_{O L S}^{2}$ is the coefficient of determination of an ordinary least squares (OLS) model with variable $i$ as the regressand and the remaining variables as regressors. $V I F_{i}$ can take any value above one, where the lower the $V I F_{i}$ the lower the multicollinearity (Gareth et al. 2017). We recalculate the $V I F_{i}$ values each time a variable is excluded from our variable set.

We find that the input variables RE/TA, BVEQ/TL, BVEQ/TA and LIQ/REV are highly correlated with each other, especially for the financial statements based on IFRS, resulting in very high $V I F_{i}$ values of above 100 . To ensure that leverage is measured by the final variable set, we select only BVEQ/TA from these four variables. Next, we exclude $\operatorname{logTA}$ as it has a high $V I F_{i}$ value even though it is not highly correlated with any other single variable. In the remaining variable set, we have two variables measuring liquidity. Among these, we exclude WC/TA as it has the highest $V I F_{i}$ value and is highly correlated with BVEQ/TA while the other liquidity variable, PA/TA, is only weakly correlated with any other variable.

Tables 2 and 3 show the $V I F_{i}$ values for each variable in the final variable set when using the financial statements based on IFRS and NGAAP, respectively, as well as the correlations between the pairs of variables. We observe no evidence of unacceptable multicollinearity for the final variable set. 
Table 2. The variance inflation factor $\left(V I F_{i}\right)$ values for each variable in the final set and the correlations between the pairs of variables when using the financial statements based on International Financial Reporting Standards (IFRS). The description of the variables is provided in Table 1.

\begin{tabular}{ccccc}
\hline Variable & VIF $_{\boldsymbol{i}}$ & EBIT/TA & BVEQ/TA & dEQ \\
\hline EBIT/TA & 1.66 & & & \\
BVEQ/TA & 1.77 & 0.23 & & \\
dEQ & 1.07 & -0.18 & -0.25 & \\
PA/TA & 1.44 & -0.05 & -0.39 & 0.13 \\
\hline
\end{tabular}

Table 3. The variance inflation factor $\left(V I F_{i}\right)$ values for each variable in the final set and the correlations between any pairs of variables when using the financial statements based on Norwegian Generally Accepted Accounting Principles (NGAAP). The description of the variables is provided in Table 1.

\begin{tabular}{ccccc}
\hline Variable & $V I F_{i}$ & EBIT/TA & BVEQ/TA & dEQ \\
\hline EBIT/TA & 1.27 & & & \\
BVEQ/TA & 1.22 & 0.32 & & \\
dEQ & 1.37 & -0.45 & -0.57 & \\
PA/TA & 1.32 & -0.20 & -0.41 & 0.23 \\
\hline
\end{tabular}

\section{Methodology}

Earlier bankruptcy prediction studies used a linear discriminant analysis to derive their models. ${ }^{6}$ However, there are several issues with using this method in economics and finance, including its assumption of a multivariate normal distribution of the input variables and equal variance-covariance matrices across the groups of classes (Joy and Tollefson 1975; Deakin 1976; Eisenbeis 1977). Consequently, LR was introduced for bankruptcy prediction by Ohlson (1980). The benefits of using LR are that it requires less restrictive assumptions and gives more intuitive outputs. ${ }^{7}$

Let the vector $\hat{\boldsymbol{y}}=\left\{\hat{\boldsymbol{y}}_{n}\right\}_{n=1 \ldots N} \in[0,1]^{N}$ determine the predicted probabilities of bankruptcy given by:

$$
\hat{y}=\iota \oslash\left(\iota+\exp \left(-X \beta-\iota \beta_{0}\right)\right)
$$

where $\boldsymbol{X}=\left\{x_{(n, i)}\right\}_{n=1, \ldots, N, i=1, \ldots, I}$ is a matrix of values for the input variables and $i$, derived from the financial statements, $n, \beta=\left\{\beta_{i}\right\}_{i=1, \ldots, I}$ and $\beta_{0}$ are the model coefficients, $\oslash$ denotes the Hadamard (elementwise) division, and $\iota$ is an $N \times 1$ vector of ones.

The coefficients are estimated by maximizing the likelihood function given by:

$$
\prod_{n=1}^{N}\left(\hat{y}_{n}\right)^{y_{n}}\left(1-\hat{y}_{n}\right)^{1-y_{n}}
$$

where $y=\left\{y_{n}\right\}_{n=1 \ldots N} \in\{0,1\}^{N}$ is the vector of actual classifications of bankrupt (1) or non-bankrupt (0) for the financial statements $n$. In practice, instead of maximizing the likelihood function, we minimize the negative of the log likelihood function given by:

$$
\ell\left(\boldsymbol{\beta}, \boldsymbol{\beta}_{0}\right)=\sum_{n=1}^{N}\left[\boldsymbol{y} \odot\left(\boldsymbol{X} \boldsymbol{\beta}+\boldsymbol{\iota} \boldsymbol{\beta}_{0}\right)-\log \left(\boldsymbol{\iota}+\exp \left(\boldsymbol{X} \boldsymbol{\beta}+\boldsymbol{\iota} \beta_{0}\right)\right)\right]
$$

6 e.g., Altman (1968); Meyer and Pifer (1970); Deakin (1972); Wilcox (1973); Blum (1974); Libby (1975); Altman and Loris (1976); Ketz (1978); and Pettway and Sinkey (1980).

7 When predicting bankruptcy using LR, where bankrupcy is labeled 1, the frequency of bankruptcies in the training data, i.e., the data used for estimating the coefficients, will always correspond to the average of the outputs from the trained LR model across all observations in the training data. Consequently, the output of the LR bankruptcy prediction model for any specific observation can be interpreted as the probability of banktuptcy. 
where $\odot$ denotes the Hadamard (element-wise) product. The minimization is conducted by following an iterative optimization algorithm. ${ }^{8}$

We predict bankruptcy in a one-year horizon, which corresponds with the practice of most practitioners and academics (Hillegeist et al. 2004; Tian et al. 2015; Tian and Yu 2017). Indeed, Appiah et al. (2015) found that one-year data were most often considered among all the bankruptcy prediction studies they reviewed and that such studies achieved remarkable results. Further, several studies on bankruptcy prediction have shown that the best prediction was made when the forecasting horizon was one year or shorter. ${ }^{9}$ By using a one-year time horizon, we comply with the Basel III regulatory framework, which states that the probability of default for bank and corporate exposures is the prediction of a one-year-ahead probability of default (Bank of International Settlements 2017).

We use an eight-fold cross-validation procedure with forward validation and a rolling window to divide the sample into eight subsamples, as illustrated in Table 4 (Kaastra and Boyd 1996; Keles et al. 2016). ${ }^{10}$ For each of the eight subsamples, we evaluate the out-ofsample performance using test data consisting of all financial statements from one of the accounting years during the period of 2011-2018. We name the subsamples in accordance with the year used for measuring out-of-sample performance. Furthermore, we train the model, i.e., estimate the coefficients $\beta$ and $\beta_{0}$, and evaluate the in-sample fit separately for each subsample using training data consisting of all financial statements from the five previous years. The procedure is carried out separately for all financial statements based on IFRS and local GAAP.

Table 4. For each of the eight subsamples, we separately train the model and evaluate the in-sample fit using training data consisting of all financial statements from five subsequent accounting years, which are given in green. We further evaluate the out-of-sample performance using test data consisting of all financial statements from the following accounting year, which are given in blue.

\begin{tabular}{|c|c|c|c|c|c|c|c|c|c|c|c|c|c|}
\hline Subsample & 2006 & 2007 & 2008 & 2009 & 2010 & 2011 & 2012 & 2013 & 2014 & 2015 & 2016 & 2017 & 2018 \\
\hline 2011 & & & & & & & & & & & & & \\
\hline 2012 & & & & & & & & & & & & & \\
\hline 2013 & & & & & & & & & & & & & \\
\hline 2014 & & & & & & & & & & & & & \\
\hline 2015 & & & & & & & & & & & & & \\
\hline 2016 & & & & & & & & & & & & & \\
\hline 2017 & & & & & & & & & & & & & \\
\hline 2018 & & & & & & & & & & & & & \\
\hline
\end{tabular}

Table 5 shows the number of financial statements based on IFRS and local GAAP within the training and test data for each of the eight subsamples. It also shows the fractions of financial statements categorized as bankrupt. We restrict the values of the input variables between the 5th and 95th percentiles as explained in Section 3 across financial statements based on IFRS and NGAAP, respectively, for each accounting year.

We evaluate the model performance using the area under the receiver operating characteristic curve (AUC), which is a widely used metric for evaluating bankruptcy prediction models. ${ }^{11}$ The receiver operating characteristic curve is a plot of the false positive rate against the true positive rate at different thresholds for defining the predicted class that an observation belongs to (Fawcett 2006; Hosmer et al. 2013). The AUC can, in practice, have any value between 0.5 and 1 , where a higher value indicates a higher

8 For minimization, we use the L-BFGS-B algorithm (Byrd et al. 1995; Zhu et al. 1997). Further, we use zero as the initial value for all coefficients $\beta$ and $\beta_{0}$ for the algorithm.

9 e.g., Altman (1968); Blum (1974); Altman et al. (1977); Moyer (1977); Ohlson (1980); Aziz et al. (1988); Altman et al. (1994, 1995); Dimitras et al. (1999); Tian et al. (2015); and Tian and Yu (2017).

10 Our results are robust to using an expanding window for enabling the utilization of all previous data when training models. Results are available upon request.

11 e.g., Duffie et al. (2007); Altman et al. (2010); Tian et al. (2015); Tian and Yu (2017); and Gupta et al. (2018). 
explanatory power. ${ }^{12}$ As a rule of thumb, an AUC between 0.7 and 0.8 is considered acceptable, while a value above 0.8 is considered excellent (Hosmer et al. 2013). When comparing different prediction models, the AUC has been found to be superior to other statistics, as it takes into account both error costs and class skewness within the data (Huang and Ling 2005).

Table 5. Number of financial statements within the training and test data for each subsample, based on International Financial Reporting Standards (IFRS) and Norwegian Generally Accepted Accounting Principles (NGAAP), respectively. The fractions of financial statements categorized as bankrupt are shown below each number.

\begin{tabular}{ccccccccc}
\hline Subsample & $\mathbf{2 0 1 1}$ & $\mathbf{2 0 1 2}$ & $\mathbf{2 0 1 3}$ & $\mathbf{2 0 1 4}$ & $\mathbf{2 0 1 5}$ & $\mathbf{2 0 1 6}$ & $\mathbf{2 0 1 7}$ & $\mathbf{2 0 1 8}$ \\
\hline IFRS & & & & & & & & \\
Training data & 35,772 & 69,046 & 104,801 & 141,986 & 180,936 & 200,151 & 215,406 & 231,768 \\
Bankrupt & $3.3 \%$ & $2.7 \%$ & $2.4 \%$ & $2.0 \%$ & $1.6 \%$ & $1.4 \%$ & $1.2 \%$ & $1.1 \%$ \\
Test data & 34,803 & 37,727 & 39,564 & 41,932 & 46,125 & 50,058 & 54,089 & 58,187 \\
Bankrupt & $1.9 \%$ & $1.8 \%$ & $1.4 \%$ & $0.9 \%$ & $1.0 \%$ & $1.1 \%$ & $1.1 \%$ & $1.1 \%$ \\
\hline GAAP & & & & & & & & \\
Training data & 620,395 & 634,431 & 650,756 & 672,262 & 702,234 & 738,792 & 778,695 & 818,318 \\
Bankrupt & $2.0 \%$ & $2.0 \%$ & $1.8 \%$ & $1.8 \%$ & $1.7 \%$ & $1.7 \%$ & $1.7 \%$ & $1.7 \%$ \\
Test data & 128,715 & 136,584 & 145,556 & 153,781 & 161,706 & 167,824 & 175,798 & 181,244 \\
Bankrupt & $1.7 \%$ & $1.8 \%$ & $1.8 \%$ & $1.7 \%$ & $1.6 \%$ & $1.8 \%$ & $1.6 \%$ & $1.3 \%$ \\
\hline
\end{tabular}

We also measure in-sample fit using the pseudo-R squared $\left(R^{2}\right)$ of McFadden (1974), which is given as:

$$
R^{2}=1-\frac{\ell\left(\beta, \beta_{0}\right)}{\ell\left(\beta_{0}\right)} \in[0,1]
$$

where $\ell\left(\beta_{0}\right)$ is the log likelihood of the null model, which does not contain any independent variables, but only the intercept coefficient $\beta_{0}$.

To determine the significance of the estimated coefficients, we use Wald statistics to assess the $z$-score of any coefficient of any input variable. ${ }^{13}$ This is given for input variable $i$ by:

$$
z_{i}=\frac{\beta_{i}}{s_{\beta_{i}}}
$$

where the denominator is the standard deviation of the numerator, which is given as $s_{\beta_{i}}=\sqrt{C_{i, i}}$, where $C=\left\{C_{j, k}\right\}_{j=1, \ldots, N, k=1, \ldots, N}$ is the variance covariance matrix, given as $\left(\boldsymbol{X}^{\prime} \boldsymbol{D} \boldsymbol{X}\right)^{-1}$, and $\boldsymbol{D}=\left\{d_{j, k}\right\}_{j=1, \ldots, N, k=1, \ldots, N}$ is a diagonal matrix with $d_{l, l}=\hat{y}_{l}\left(1-\hat{y}_{l}\right)$.

\section{Results and Discussions}

Tables 6 and 7 show the estimated coefficient values and model evaluations across the eight subsamples for the accounting years of 2011-2018, when considering the financial statements based on IFRS and NGAAP, respectively. The values in parentheses are the $z$ scores. The in-sample fit is evaluated by $R^{2}$ and AUC, while the out-of-sample performance is evaluated using AUC.

12 In theory, AUC can have a value below 0.5 which represents an unrealistic model.

13 The reader is referred to page 330 in Ryan (2018) and page 40 in Hosmer et al. (2013) for details on Wald statistics. 
Table 6. Results across the eight subsamples for the accounting years of 2011-2018, when considering the financial statements based on International Financial Reporting Standards (IFRS). We show the estimated coefficient values of the logistic regression (LR) model, with the $z$-scores in parentheses. The input variables are detailed in Table 1 . We report the in-sample fit using $R^{2}$ and area under the receiver operating characteristic curve (AUC) and the out-of-sample performance using AUC.

\begin{tabular}{|c|c|c|c|c|c|c|c|c|}
\hline Variable/Metric & 2011 & 2012 & 2013 & 2014 & 2015 & 2016 & 2017 & 2018 \\
\hline constant & $\begin{array}{c}-2.75 \\
(-89.98)\end{array}$ & $\begin{array}{c}-2.89 \\
(-117.53)\end{array}$ & $\begin{array}{c}-3.05 \\
(-144.18)\end{array}$ & $\begin{array}{c}-3.18 \\
(-161.81)\end{array}$ & $\begin{array}{c}-3.51 \\
(-179.37)\end{array}$ & $\begin{array}{c}-3.63 \\
(-183.18)\end{array}$ & $\begin{array}{c}-3.72 \\
(-184.4)\end{array}$ & $\begin{array}{c}-3.81 \\
(-186.99)\end{array}$ \\
\hline EBIT/TA & $\begin{array}{c}-2.56 \\
(-11.51)\end{array}$ & $\begin{array}{c}-2.75 \\
(-14.46)\end{array}$ & $\begin{array}{c}-2.67 \\
(-15.87)\end{array}$ & $\begin{array}{c}-2.58 \\
(-15.83)\end{array}$ & $\begin{array}{c}-2.73 \\
(-15.92)\end{array}$ & $\begin{array}{c}-2.52 \\
(-14.71)\end{array}$ & $\begin{array}{c}-2.35 \\
(-13.77)\end{array}$ & $\begin{array}{c}-2.17 \\
(-12.96)\end{array}$ \\
\hline BVEQ/TA & $\begin{array}{c}-3.84 \\
(-27.29)\end{array}$ & $\begin{array}{c}-4.17 \\
(-37.02)\end{array}$ & $\begin{array}{c}-4.32 \\
(-44.30)\end{array}$ & $\begin{array}{c}-4.78 \\
(-50.18)\end{array}$ & $\begin{array}{c}-4.54 \\
(-49.01)\end{array}$ & $\begin{array}{c}-4.60 \\
(-49.13)\end{array}$ & $\begin{array}{c}-4.51 \\
(-48.38)\end{array}$ & $\begin{array}{c}-4.32 \\
(-47.48)\end{array}$ \\
\hline $\mathrm{dEQ}$ & $0.53(8.58)$ & $0.74(14.94)$ & $0.87(20.62)$ & $0.97(25.22)$ & 1.05 (27.39) & $1.11(29.00)$ & $1.12(27.95)$ & $1.12(26.96)$ \\
\hline PA/TA & $1.39(13.40)$ & $1.80(20.70)$ & $2.29(30.32)$ & $2.60(36.87)$ & $2.94(41.77)$ & $3.00(41.79)$ & $2.91(39.01)$ & $2.78(36.25)$ \\
\hline$R^{2}$ & 0.19 & 0.22 & 0.23 & 0.24 & 0.22 & 0.22 & 0.22 & 0.20 \\
\hline In-sample AUC & 0.80 & 0.82 & 0.83 & 0.84 & 0.84 & 0.84 & 0.83 & 0.82 \\
\hline Out-of-sample AUC & 0.84 & 0.84 & 0.85 & 0.83 & 0.83 & 0.81 & 0.80 & 0.82 \\
\hline
\end{tabular}

Table 7. Results across the eight subsamples for the accounting years of 2011-2018, when considering the financial statements based on Norwegian Generally Accepted Accounting Principles (NGAAP). We show the estimated coefficient values of the logistic regression (LR) model, with the $z$-scores in parentheses. The input variables are detailed in Table 1. We report the in-sample fit using $R^{2}$ and area under the receiver operating characteristic curve (AUC) and the out-of-sample performance using AUC.

\begin{tabular}{|c|c|c|c|c|c|c|c|c|}
\hline Variable/Metric & 2011 & 2012 & 2013 & 2014 & 2015 & 2016 & 2017 & 2018 \\
\hline Constant & $\begin{array}{c}-4.89 \\
(-522.56)\end{array}$ & $\begin{array}{c}-4.93 \\
(-528.47)\end{array}$ & $\begin{array}{c}-4.98 \\
(-522.25)\end{array}$ & $\begin{array}{c}-4.95 \\
(-518.98)\end{array}$ & $\begin{array}{c}-4.91 \\
(-531.88)\end{array}$ & $\begin{array}{c}-4.93 \\
(-543.10)\end{array}$ & $\begin{array}{c}-4.88 \\
(-552.90)\end{array}$ & $\begin{array}{c}-4.84 \\
(-559.44)\end{array}$ \\
\hline EBIT/TA & $\begin{array}{c}-1.21 \\
(-40.20)\end{array}$ & $\begin{array}{c}-1.16 \\
(-38.68)\end{array}$ & $\begin{array}{c}-1.11 \\
(-36.64)\end{array}$ & $\begin{array}{c}-1.07 \\
(-34.21)\end{array}$ & $\begin{array}{c}-1.03 \\
(-34.08)\end{array}$ & $\begin{array}{c}-0.88 \\
(-30.33)\end{array}$ & $\begin{array}{c}-0.86 \\
(-31.68)\end{array}$ & $\begin{array}{c}-0.80 \\
(-30.80)\end{array}$ \\
\hline BVEQ/TA & $\begin{array}{c}-0.89 \\
(-38.44)\end{array}$ & $\begin{array}{c}-0.85 \\
(-37.41)\end{array}$ & $\begin{array}{c}-0.89 \\
(-39.53)\end{array}$ & $\begin{array}{c}-0.94 \\
(-42.57)\end{array}$ & $\begin{array}{c}-0.92 \\
(-44.17)\end{array}$ & $\begin{array}{c}-0.83 \\
(-41.86)\end{array}$ & $\begin{array}{c}-0.81 \\
(-44.24)\end{array}$ & $\begin{array}{c}-0.84 \\
(-49.19)\end{array}$ \\
\hline $\mathrm{dEQ}$ & $1.11(102.57)$ & $1.12(103.42)$ & $1.07(96.73)$ & $0.98(87.60)$ & $0.93(85.33)$ & $0.93(86.65)$ & $0.87(82.60)$ & $0.81(77.60)$ \\
\hline $\mathrm{PA} / \mathrm{TA}$ & $2.61(93.90)$ & $2.76(98.63)$ & $2.79(97.55)$ & $2.83(99.07)$ & $2.95(107.14)$ & $3.00(109.81)$ & $2.95(110.33)$ & $2.86(108.58)$ \\
\hline$R^{2}$ & 0.22 & 0.23 & 0.22 & 0.21 & 0.20 & 0.19 & 0.18 & 0.17 \\
\hline In-sample AUC & 0.83 & 0.83 & 0.83 & 0.82 & 0.81 & 0.81 & 0.80 & 0.80 \\
\hline Out-of-sample AUC & 0.83 & 0.82 & 0.81 & 0.78 & 0.79 & 0.80 & 0.80 & 0.82 \\
\hline
\end{tabular}

We observe that the values of $R^{2}$, in-sample AUC, and out-of-sample AUC are mostly higher for the financial statements based on IFRS, compared to those based on NGAAP. ${ }^{14}$ This could be attributed to the increased transparency under IFRS, which prevents managers from using creative accounting practices to manipulate accounting reports in order to hide their true situation. Our findings also seem consistent with the literature, claiming improvements in financial reporting quality through IFRS adoption. Moreover, the AUC is close to or above 0.8 in all cases, which indicates that the accounting-based input variables in our study can accurately predict bankruptcy. Further, we observe stable coefficient estimates across the years, with high $z$-scores, indicating that all are significant.

The coefficient estimates for EBIT/TA have negative signs in all cases. This is expected, as higher values of these variables translate to relatively higher earnings and savings and thus a lower probability of going bankrupt. Furthermore, the magnitudes of these coefficients are greater under IFRS than NGAAP. The reason for this may be that NGAAP allow for the amortization of goodwill, while IFRS demand an impairment test, which yields more transparency. Furthermore, IFRS require the classification of development expenditures as intangible assets, whereas NGAAP allow them to be recognized as expenses. This

14 In this regard it should be noted that models resulting in only slight improvement in AUC scores have been shown to be superior at predicting bankruptcies resulting in potentially huge profit gains for creditors who use such models for credit decisions (Agarwal and Taffler 2008; Paraschiv et al. 2021). 
can lead to an understatement of net income under NGAAP, which indicates that IFRS could be better suited to predicting company bankruptcy (Franzen et al. 2007).

The coefficient estimates for BVEQ/TA are negative under both IFRS and NGAAP. This is also in accordance with our expectations as it suggests that a higher rate of equity compared to debt lowers the probability of going bankrupt. However, the magnitudes of the coefficients are greater under IFRS than NGAAP. This may be due to IFRS being more conservative when it comes to accounting for intangibles. For instance, brands cannot be recognized as intangible assets under IFRS (IFRS Foundation 2021) while under NGAAP, they can. Another reason may be that IFRS require the recognition of more liabilities, such as long- and short-term employee benefits, termination benefits, and pension obligations, all of which increase liabilities and salary expenses. This lowers the value of BVEQ as higher expenses decrease retained earnings.

The coefficient estimates for $\mathrm{AEQ}$ are positive in all cases, which is logical as it suggests an increase in the probability of going bankrupt if the book value of equity falls below the paid-in equity. The coefficient values are higher under NGAAP than IFRS. This may be due to the lower retained earnings under IFRS as discussed above, which results in companies being worse off when dEQ is equal to one under NGAAP rather than IFRS.

The magnitudes of the coefficients for PA/TA are relatively similar under both NGAAP and IFRS. In all cases the signs are positive, which is as expected since it means that more trade payables increase the probability of going bankrupt.

\section{Limitations and Suggestions for Future Research}

Our study has some limitations. First, while we argue that cross country differences can be deemed negligible in our study, our research design does not capture any differences in firm characteristics. Second, it is difficult to obtain enough financial reports for model estimation and evaluation from the same companies and same accounting years reported based on both IFRS and local GAAP, respectively, as most companies make financial statements for any accounting year under a single set of accounting standards. Moreover, very few privately held companies report under IFRS in Norway.

While we analyze the role of IFRS through bankruptcy prediction only with Swedish and Norwegian data, we recommend future research to explore this issue in other markets with local GAAP of other countries. Furthermore, if possible, we recommend investigating the differences between IFRS and local GAAP by considering the same financial reports based on both IFRS and local GAAP separately.

\section{Conclusions and Implications}

This paper examined the impact of using IFRS on the transparency of financial reporting through bankruptcy prediction models using accounting-based input variables. We started with a set of variables taken from Altman (1968) and the SEBRA model developed by the central bank of Norway. We then excluded variables such that our final variable set showed no evidence of unacceptable multicollinearity. By using logistic regression and a comprehensive sample of privately held Norwegian and Swedish companies, our results indicate that financial reports using IFRS may yield better bankruptcy prediction models compared to financial reports using NGAAP. While our results show that the use of IFRS can help in providing a better picture of a company's financial health, our research design does not capture all differences in firm characteristics. This is due to the difficulties in obtaining the same financial statements of any particular company, derived under both IFRS and local GAAP separately, as most companies, especially private ones, make financial statements for any given accounting year under a single set of accounting standards. Hence, we urge caution while interpreting our results.

Our findings have implications for several stakeholders, as well as for the development and application of accounting. The increased performance of bankruptcy prediction models under IFRS could mean that the strict accounting regulations under IFRS improve transparency, which prevents managers of firms facing insolvency from hiding their com- 
pany's true situation by engaging in creative accounting practices or window dressing of the accounts. For example, IAS 38 constrains managers from capitalizing on certain intangible assets such as brands (IFRS Foundation 2021), thereby limiting the opportunity for the overstatement of total assets. Overall, improved transparency under IFRS should aid in providing a clearer picture to investors and creditors who can then make a sound decision on investing or lending funds to companies. For standard setters, our results provide empirical evidence of the benefits of aligning accounting standards towards IFRS, and how abandoning strict accounting practices could impact bankruptcy prediction. While there are several benefits of using IFRS, it may, however, generate extra costs for companies' accounting departments.

Author Contributions: Conceptualization, A.K. and R.R.W.; methodology, A.K. and R.R.W.; software, R.R.W.; validation, A.K. and R.R.W.; formal analysis, R.R.W.; investigation, A.K. and R.R.W.; resources, A.K. and R.R.W.; data curation, A.K. and R.R.W.; writing—original draft preparation, A.K.; writing-review and editing, A.K. and R.R.W.; visualization, A.K. and R.R.W. Both authors have read and agreed to the published version of the manuscript.

Funding: This research received no external funding.

Acknowledgments: We appreciate the many insightful comments from the editor, three anonymous reviewers, Trond Kristoffersen and Per Bjarte Solibakke. We are also grateful for the helpful comments from the conference participants at the NTNU Business School Conference 2018.

Conflicts of Interest: The authors declare no conflict of interest.

\section{References}

Agarwal, Vineet, and Richard Taffler. 2008. Comparing the performance of market-based and accounting-based bankruptcy prediction models. Journal of Banking and Finance 32: 1541-51. [CrossRef]

Altman, Edward I. 1968. Financial ratios, discriminant analysis and the prediction of corporate bankruptcy. The Journal of Finance 23: 558-609. [CrossRef]

Altman, Edward I. 1993. Corporate Financial Distress and Bankruptcy: A Complete Guide to Predicting E Avoiding Distress and Profiting from Bankruptcy, 2nd ed. New York: Wiley.

Altman, Edward I., and Bettina Loris. 1976. A financial early warning system for over-the-counter broker-dealers. The Journal of Finance 31: 1201-17. [CrossRef]

Altman, Edward I., Robert G. Haldeman, and Pual Narayanan. 1977. ZETA analysis a new model to identify bankruptcy risk of corporations. Journal of Banking and Finance 1: 29-54. [CrossRef]

Altman, Edward I., Giancarlo Marco, and Franco Varetto. 1994. Corporate distress diagnosis: Comparisons using linear discriminant analysis and neutral networks (the Italian experience). Journal of Banking and Finance 18: 505-29. [CrossRef]

Altman, Edward I., Young Ho Eom, and Dong Won Kim. 1995. Failure prediction: Evidence from Korea. Journal of International Financial Management and Accounting 6: 230-49. [CrossRef]

Altman, Edward I., Gabriele Sabato, and Nicholas Wilson. 2010. The value of non-financial information in small and medium-sized enterprise risk management. The Journal of Credit Risk 6: 95-127. [CrossRef]

Altman, Edward I., Malgorzata Iwanicz-Drozdowska, Erkki K. Laitinen, and Arto Suvas. 2017. Financial distress prediction in an international context: A review and empirical analysis of Altman's Z-score model. Journal of International Financial Management and Accounting 28: 131-71. [CrossRef]

Appiah, Kingsley Opoku, Amon Chizema, and Joseph Arthur. 2015. Predicting corporate faliure: A systematic literature review of methodological issues. International Journal of Law and Management 57: 461-85. [CrossRef]

Ates, Sinem. 2021. Accounting Convergence, Mandatory Adoption of IFRS and Accounting Quality. In Handbook of Research on Institutional, Economic, and Social impacts of Globalization and Liberalization. Edited by Yilmaz Bayar. Hershey: IGI Global, pp. 605-27.

Aziz, Abdul, David C. Emanuel, and Gerald H. Lawson. 1988. Bankruptcy prediction-An investigation of cash flow based models. Journal of Management Studies 25: 419-37. [CrossRef]

Bank of International Settlements. 2017. Basel III: Finalising Post-Crisis Reforms. Report. Basel: Bank of International Settlements.

Bărbută-Misu, Nicoleta, and Mara Madaleno. 2020. Assessment of Bankruptcy Risk of Largen Companies: European Countries Evolution Analysis. Journal of Risk and Financial Management 13: 58. [CrossRef]

Barth, Mary E., Wayne R. Landsman, and Mark H. Lang. 2008. International accounting standards and accounting quality. Journal of Accounting Research 46: 467-98. [CrossRef]

Bartov, Eli, Stephen R. Goldberg, and Myungsun Kim. 2005. Comparative value relevance among German, U.S., and International Accounting Standards: A German stock market perspective. Journal of Accounting, Auditing E Finance 20: 95-119.

Begley, Joy, Jin Ming, and Susan Watts. 1996. Bankruptcy classification errors in the 1980's: An empirical analysis of Altman's and Ohlson's models. Review of Accounting Studies 1: 267-84. [CrossRef] 
Bernhardsen, Eivind, and Kai Larsen. 2007. Modelling credit risk in the enterprise sector - further development of the SEBRA model. Economic Bulletin 78: 102-8.

Bhat, Gauri, Jeffrey L. Gallen, and Dan Segal. 2014. Credit risk and IFRS: The case of Credit Default Swaps. Journal of Accounting, Auditing E Finance 29: 129-62. [CrossRef]

Blum, Marc. 1974. Failing company discriminant analysis. Journal of Accounting Research 12: 1-25. [CrossRef]

Bodle, Kerry Anne, Patti J. Cybinski, and Reza Monem. 2016. Effect of IFRS adoption on financial reporting quality: Evidence from bankruptcy prediction. Accounting Research Journal 29: 292-312. [CrossRef]

Botosan, Christine A., and Marlene A. Plumlee. 2002. A Re-examination of Disclosure Level and the Expected Cost of Equity Capital. Journal of Accounting Research 40: 21-40. [CrossRef]

Byard, Donal, Ying Li, and Yong Yu. 2010. The effect of mandatory IFRS adoption on financial analysts' information environment. Journal of Accounting Research 49: 69-96. [CrossRef]

Byrd, Richard H., Peihuang LU, Jorge Nocedal, and Ciyou Zhu. 1995. A limited memory algorithm for bound constrained optimization. SIAM Journal on Scientific Computing 16: 1190-208. [CrossRef]

Campbell, John Y., Jens Hilscher, and Jan Szilagyi. 2008. In search of distress risk. The Journal of Finance 63: 2899-939. [CrossRef]

Charitou, Andreas, Irene Karamanou, and Neophytos Lambertides. 2015. Who are the losers of IFRS adoption in Europe? An empirical examination of the cash flow effect of increased disclosure. Journal of Accounting, Auditing E Finance 30: 150-80. [CrossRef]

Choi, Young-Soo, Ken Peasnell, and Joao Toniato. 2013. Has the IASB been successful in making accounting earnings more useful for prediction and valuation? UK evidence. Journal of Business Finance E Accounting 40: 741-68. [CrossRef]

Christiansen, Hans B, Edward Lee, Martin Walker, and Cheng Zheng. 2015. Incentives or standards: What determines accounting quality changes around IFRS adoption? European Accounting Review 24: 31-61. [CrossRef]

Cordazzo, Michela, and Paola Rossi. 2020. The influence of IFRS mandatory adoption on value relevance of intangible assets in Italy. Journal of Applied Accounting Research 21: 415-36. [CrossRef]

Deakin, Edward B. 1972. A discriminant analysis of predictors of business failure. Journal of Accounting Research 10: 167-79. [CrossRef]

Deakin, Edward B. 1976. Distributions of fnancial accounting ratios: Some empirical evidence. The Accounting Review 51: 90-96.

Diamond, Douglas W., and Robert E. Verrecchia. 1991. Disclosure, Liquidity and the Cost of Capital. The Journal of Finance 46: 1325-59. [CrossRef]

Dimitras, Augustinos I., Roman Slowinski, Robert Susmaga, and Constantin Zopounidis. 1999. Business faliure prediction using rough sets. European Journal of Operational Research 114: 263-80. [CrossRef]

Duffie, Darrell, Leandro Saita, and Ke Wang. 2007. Multi-period corporate default prediction withstochastic covariates. Journal of Financial Economics 83: 635-65. [CrossRef]

Eisenbeis, Robert A. 1977. Pitfalls in the application of discriminant analysis in Business, Finance and Economics. The Journal of Finance 32: 875-900. [CrossRef]

Fan, Jingting, and Sebnem Kalemli-Ozcan. 2015. Emergence of Asia: Reforms, corporate savings, and global imbalances. IMF Economic Review 64: 239-67. [CrossRef]

Fawcett, Tom. 2006. An introduction to ROC analysis. Pattern Recognition Letters 27: 861-74. [CrossRef]

Florou, Annita, and Urska Kosi. 2015. Does mandatory IFRS adoption facilitate debt financing? Review of Accounting Studies 20: 1407-56. [CrossRef]

Florou, Annita, Urska Kosi, and Peter F. Pope. 2017. Are international accounting standards more credit relevant than domestic standards? Accounting and Business Research 47: 1-29. [CrossRef]

Fossung, Micheal Frozeh, Lious Agbor Tabot Ntuong, Helena Maria Santos de Oliveira, Cláudia Maria Ferreira Pereira, Susana Adelina Moreira Carvalho Bastos, and Liliana Marques Pimentel. 2020. Transition to the Revised OHADA Law on Accounting and Financial Reporting: Corporate Perceptions of Costs and Benefits. Journal of Risk and Financial Management 13: 172. [CrossRef]

Franzen, Laurel A., Kimberly J. Rodgers, and Timothy T. Simin. 2007. Measuring Distress Risk: The Effectof R\&D Intensity. The Journal of Finance 62: 2391-967. [CrossRef]

Gareth, James, Daniela Witten, Trevor Hastie, and Robert Tibshirani. 2017. An Introduction to Statistical Learning: With Applications in R, 7 th ed. New York: Springer.

George, Emmanuel T. De, Xi Li, and Lakshmanan Shivakumar. 2016. A review of the IFRS adoption literature. Review of Accoutning Studies 21: 898-1004. [CrossRef]

Gjerde, Øystein, Kjell Knivsflå, and Frode Sættem. 2008. The value-relevance of adopting IFRS: Evidence from 145 NGAAP restatements. Journal of International Accounting, Auditing and Taxation 17: 97-112. [CrossRef]

Grice, John Stephen, and Robert W. Ingram. 2001. Tests of the generalizability of Altman's bankruptcy prediction model. Journal of Business Research 54: 53-61. [CrossRef]

Guermazi, Walid, and Khamoussi Halioui. 2020. Do differences in national cultures affect cross-country conditionalconservatism behavior under IFRS? Research in International Business and Finance 52: 1-13. [CrossRef]

Güleç, Ömer Faruk. 2021. Value Relevance of Intangibles: A Literature Review. In Ethics and Sustainability in Accounting and Finance. Edited by Kıymet Tunca Çalıyurt. Singapore: Springer Nature Singapore Pte Ltd. 
Günther, Nina, Bernhard Gegenfurtner, Christoph Kaserer, and Ann-Kristin Achleitner. 2009. International Financial Reporting Standards and Earnings Quality: The Myth of Voluntary vs. Mandatory Adoption. Working Paper. München: Center for Entrepreneurial and Financial Studies (CEFS), Technische Universität München, Available online: https://www.econstor.eu/handle/10419/48427 (accessed on 15 February 2021).

Gupta, Jairaj, Andros Gregoriou, and Tahera Ebrahimi. 2018. Empirical comparison of hazard models in predicting SMEs failure. Quantitative Finance 18: 437-66. [CrossRef]

Hillegeist, Stephen A., Elizabeth K. Keating, Donald P. Cram, and Kyle G. Lundstedt. 2004. Assessing the probability of bankruptcy. Review of Accounting Studies 9: 5-34. [CrossRef]

Hofstede Insights. 2020. Country Comparison. Available online: https:/ /www.hofstede-insights.com/country-comparison/norway, sweden/ (accessed on 1 January 2021).

Horten, Joanne, and George Serafeim. 2010. Market reaction to and valuation of IFRS reconciliation adjustments: First evidence from the UK. Review of Accounting Studies 15: 725-51. [CrossRef]

Hosmer, David W., Stanley Lameshow, and Rodney X. Sturdivant. 2013. Applied Logistic Regression. New York: John Wiley \& Sons.

Huang, Jin, and Charles X. Ling. 2005. Using AUC and accuracy in evaluating learning algorithms. IEEE Transactions on Knowledge and Data Engineering 17: 299-310. [CrossRef]

Hung, Mingyi, and K. R. Subramanyam. 2007. Financial statement effects of adopting international accounting standards: The case of Germany. Review of Accounting Studies 12: 623-57. [CrossRef]

IFRS Foundation. 2016. IFRS Application around the World. Available online: https://www.ifrs.org/-/media/feature/around-theworld/jurisdiction-profiles/sweden-ifrs-profile.pdf (accessed on 15 February 2021).

IFRS Foundation. 2020. IFRS-Who We Are. Available online: https://www.ifrs.org/about-us/who-we-are/\#history (accessed on 15 February 2021).

IFRS Foundation. 2021. IFRS Standards. London: IFRS Foundation.

International Standards Accounting Board. 2002. International Accounting Standards Comittee Foundation. London: International Standards Accounting Board.

Joy, O. Maurice, and John O. Tollefson. 1975. On the financial applications of discriminant analysis. The Journal of Financial and Quantitative Analysis 10: 723-39. [CrossRef]

Kaastra, Iebeling, and Milton Boyd. 1996. Designing a neural network for forecasting financial and economic time series. Neurocomputing 10: 215-36. [CrossRef]

Kanagaretnam, Kiridaran, Chee Yeow Lim, and Gerald J. Lobo. 2014. Influence of national culture on accounting conservatism and risk-taking in the banking industry. The Accounting Review 89: 1115-49. [CrossRef]

Keles, Dogan, Jonathan Scelle, Florentina Paraschiv, and Wolf Fichtner. 2016. Extended forecast methods for day-ahead electricity spot prices applying artificial neural networks. Applied Energy 162: 218-30. [CrossRef]

Ketz, J. Edward. 1978. The effect of general price-level adjustments on the predictive ability of financial ratios. Journal of Accounting Research 16: 273-84. [CrossRef]

Kraft, Pepa, and Wayne R. Landsman. 2020. Effect of mandatory IFRS adoption on accounting-based prediction models for CDS spreads. European Accounting Review. [CrossRef]

Kristoffersen, Trond. 2020. Opphev bestemmelsene om grunnleggende regnskapsprinsipper. Revisjon og Regnskap 4: 41-47.

Kwon, Soo Young, Kyunga Na, and Jongil Park. 2019. The economic effects of IFRS adoption in Korea. Asia-pacific Journal of Accounting and Economics 26: 321-61. [CrossRef]

Lambert, Richard, Christian Leuz, and Robert E. Verrecchia. 2007. Accounting information, disclosure and the cost of capital. Journal of Accounting Research 45: 385-420. [CrossRef]

Levitt, Arthur. 1998. The importance of high quality accounting standards. Accounting Horizons 12: 79-82.

Libby, Robert. 1975. Accounting ratios and the prediction of failure: Some behavioral evidence. Journal of Accounting Research 13: 150-61. [CrossRef]

Mansi, Sattar A., William F. Maxwell, and Andrew Zhang. 2012. Bankruptcy prediction models and the cost of debt. The Journal of Fixed Income 21: 25-42. [CrossRef]

Marton, Jan. 2017. The Role and Current Status of IFRS in the Completion of National Accounting Rules-Evidence from Sweden. Accounting in Europe 14: 207-16. [CrossRef]

Masoud, Najeb. 2017. The effects of mandatory IFRS adoption on financial analysts' forecast: Evidence from Jordan. Cogent Business and Management 4: 1290331. [CrossRef]

McFadden, Daniel. 1974. Conditional logit analysis of qualitative choice behaviour. In Frontier in Econometrics. Edited by Paul Zarembka. New York: New York Academic Press, pp. 105-42.

Meyer, Paul A., and Howard W. Pifer. 1970. Prediction of bank failures. The Journal of Finance 25: 853-68. [CrossRef]

Moyer, R. Charles. 1977. Forecasting financial failure: A re-examination. Financial Management (pre-1986) 6: 11-17. [CrossRef]

Ntoung, Lious Agbor Tabot, Helena Maria Santos de Oliveira, Benjamim Manuel Ferreira de Sousa, Liliana Marques Pimentel, and Susana Adelina Moreira Carvalho Bastos. 2020. Are Family Firms Financially Healthier Than Non-Family Firm? Journal of Risk and Financial Management 13: 5. [CrossRef]

Ohlson, James A. 1980. Financial ratios and the probablistic prediction of bankruptcy. Journal of Accounting Research 18: 109-31. [CrossRef] 
Oliveira, Lidia, Lucia Lima Rodriguez, and Russel Craig. 2010. Intangible assets and value relevance: Evidence from the Portuguese stock exchange. The British Accounting Review 42: 241-52. [CrossRef]

Orbis. 2007. ORBIS Internet User Guide. Brussels: Bureau van Dijk Electronic Publishing.

Norwegian Accounting Standards Board. 2012. NRS 19 Immaterielle Eiendeler. Available online: https:/ / www.regnskapsstiftelsen. no/regnskap/regnskapsstandarder/nrs-19-immaterielle-eiendeler (accessed on 8 February 2021).

Paolone, Francesco, Ricardo Tiscini, and Laura Martiniello. 2020. Accounting and Value Relevance of Intangibles: A longitudinal Study in Italian Stock Exchange 2010-2018. Journal of Modern Accounting and Auditing 16: 201-10. [CrossRef]

Paraschiv, Florentina, Markus Schmid, and Ranik Raaen Wahlstrøm. 2021. Bankruptcy Privately Held SME's Using Feature Selection Methods. Working Paper. Trondheim: NTNU Business School, Norwegian University of Science and Technology, St. Gallen: University of St. Gallen.

Pettway, Richard H., and Joseph F. Sinkey. 1980. Establishing on-site bank examination priorities: An early warning system using accounting and market information. The Journal of Finance 35: 137-50. [CrossRef]

Picker, Ruth, Kerry Clark, John Dunn, David Kolitz, Gilad Livne, Janice Loftus, and Leo van der Tas. 2016. Applying IFRS Standards, 4th ed. Great Britain: Wiley.

Ryan, Thomas P. 2018. Modern Regression Methods, 2nd ed. Hoboken: John Wiley \& Sons.

Shyam-Sunder, Lakshmi, and Stewart C. Myers. 1999. Testing static tradeoff against pecking order models of capital structure. Journal of Financial Economics 51: 219-44. [CrossRef]

Singleton-Green, Brian. 2015. The Effects of Mandatory IFRS Adoption in the EU: A Review of Empirical Research. Information for Better Markets. ICAEW Financial Reporting Quality. London: ICAEW.

Tan, Hongping, Shiheng Wang, and Michael Welker. 2011. Analyst following and forecast accuracy after mandated IFRS adoptions. Journal of Accounting Research 49: 1307-57. [CrossRef]

Tian, Shaonan, and Yan Yu. 2017. Financial ratios and bankruptcy prediction: An international Evidence. International Review of Economics and Finance 51: 510-26. [CrossRef]

Tian, Shaonan, Yan Yu, and Hui Guo. 2015. Variable selection and corporate bankruptcy forecasts. Journal of Banking and Finance 52: 89-100. [CrossRef]

Vo, Duc Hong, Binh Ninh Vo Pham, Chi Minh Ho, and Michael McAleer. 2019. Corporate Financial Distress of Industry Level Listings in Vietnam. Journal of Risk and Financial Management 12: 155. [CrossRef]

Wang, Xin, Danqing Young, and Zili Zhuang. 2008. The Effects of Mandatory Adoption of International Financial Reporting Standards on Information Environments. Working Paper. Hong Kong: The Chinese University of Hong Kong.

Wilcox, Jarrod W. 1973. A prediction of business failure using accounting data. Journal of Accounting Research 11: 163-79. [CrossRef]

$\mathrm{Wu}$, Joanna Shuang, and Ivy Xiying Zhang. 2014. The adoption of Internationally Recognized Accounting Standards: Implications for the credit markets. Journal of Accounting, Auditing and Finance 29: 95-128. [CrossRef]

Zhu, Ciyou, Richard H. Byrd, Peihuang Lu, and Jorge Nocedal. 1997. Algorithm 7788: L-BFGS-B: Fortran subroutines for large-scale bound-constrained optimization. ACM Transactions on Mathematical Software 23: 550-60. [CrossRef]

Zmijewski, Mark E. 1984. Methodological issues related to the estimation of financial distress prediction models. Journal of Accounting Research 22: 59-82. [CrossRef] 